\title{
Characterization of Asian swamp eel (Monopterus sp.) protein hydrolysate functional properties prepared using Alcalase ${ }^{\circledR}$ enzyme
}

\author{
Halim, N.R.A. and * Sarbon, N.M. \\ School of Food Science and Technology, Universiti Malaysia Terengganu, 21030 Kuala Nerus, \\ Terengganu, Malaysia
}

\begin{abstract}
Article history:
Received: 28 May 2019

Received in revised form: 21

June 2019

Accepted: 23 June 2019

Available Online: 30 June 2019
\end{abstract}

\section{Keywords:}

Asian swamp eel,

Protein hydrolysate,

Hydrolysis,

Alcalase ${ }^{\circledR}$,

Structural properties

DOI:

https://doi.org/10.26656/fr.2017.4(1).205

\begin{abstract}
Fish protein hydrolysates have good nutritional properties and thus can be obtained by treatment of fish meat with enzymes under controlled conditions. It is used for texturing, gelling, foaming, emulsification, protein supplements, flavor enhancers, and beverage stabilizers. The aims of this study were to prepare eel protein hydrolysate (EPH) prepared using Alcalase ${ }^{\circledR}$ enzyme and characterize its physicochemical properties. The structural, solubility, emulsifying and foaming properties, water holding and oil binding capacity of EPH were examined. Structural results obtained found that the presence of hydrophilic and hydrophobic amino acids together with the presence of aromatic groups. There were no significant differences ( $p>0.05$ ) between EPH at different $\mathrm{pH}$ levels in solubility. However, in terms of emulsifying and foaming properties, EPH showed significant differences $(\mathrm{p}<0.05)$ at different $\mathrm{pH}$ levels, while water holding capacity showed significant differences $(p<0.05)$ at different EPH concentrations. There were no significant differences ( $p>0.05)$ in the oil binding capacities of EPH at different concentrations. The functional properties possessed by EPH showed that it has potential as an emulsifier and stabilizer in food products, playing an important role in the food industry.
\end{abstract}

\section{Introduction}

Hydrolysis of fish protein has been widely conducted to obtain a valuable food ingredient with good functional properties for the food industry (Yin et al., 2010). Different techniques such as enzymatic hydrolysis, autolysis and thermal hydrolysis have been used to produce hydrolysates from fish and its by-products (Molla and Hovannisyan, 2011; Prabha et al., 2013; Wang et al., 2013). Among these techniques, enzymatic hydrolysis with various types of enzymes such as Alcalase $\AA$, protamex, neutrase, trypsin, pepsin and $\alpha$ chymotrypsin is the most used by researchers (Chalamaiah et al., 2012). There has been a great deal of research conducted in producing fish protein hydrolysates from different fish sources hydrolyzed using Alcalase ${ }^{\circledR}$, such as skipjack, tilapia and shortfin scad (Intarasirisawat et al., 2012; Wang et al., 2013; Ishak and Sarbon, 2016).

The use of proteases in the production of protein hydrolysate is frequently an attractive means for improving functional properties of food proteins by modifying their physical and chemical properties while maintaining their nutritional value (Taheri et al., 2013; Elavarasan et al., 2014). Many studies have demonstrated good functional properties in terms of solubility, emulsifying properties, foaming properties, water holding capacity and oil or fat binding capacity for fish hydrolysates prepared using proteolytic enzymes (Nalinanon et al., 2011; Jemil et al., 2014). Besides that, the structural characteristics of fish hydrolysates are also the concern of researchers (Li et al., 2013; Roslan et al., 2014). In addition, Halim et al. (2016) had thoroughly reviewed the functional properties as well as structural properties of fish protein hydrolysates.

The Asian swamp eel (Monopterus sp.) is a potential source of fish protein hydrolysate due to its nutritional value and benefits in Eastern medicine (Khanh and Ngan, 2010). This species has several characteristics of a good invader - tolerance of a wide range of temperatures, the ability to breathe air, possible dispersal across basin divides during rainy periods, the ability to burrow into sediments to survive drought, a generalized diet, and parental care of eggs (Hill and Watson, 2007). The eel's special characteristics have attracted many researchers to conduct studies on this fish in various fields. For example, a study conducted by Pederson et al. (2014), investigated the effects of salinity on osmoregulation, growth, and survival in Asian swamp eel (Monopterus albus). The hydrolysis of eel and its properties has also 
been conducted by several researchers (Yanan et al., 2012; Jamil et al., 2016; Baharuddin et al., 2016).

The application of enzyme technology to recover and modify fish proteins may produce a broad spectrum of food ingredients and industrial products for a wide range of applications (Taheri et al., 2013). The incorporation of fish hydrolysates in cereals, fish and meat products, desserts and crackers had been practiced as early as 2000 (Chalamaiah et al., 2012). In order to explore the potential of eel protein hydrolysate (EPH) as a functional ingredient in food production, this study was aimed to prepare EPH and determine its structural properties by Fourier Transform Infrared (FTIR) Spectroscopy as well as functional properties of EPH produced enzymatically using Alcalase ${ }^{\circledR}$.

\section{Materials and methods}

\subsection{Materials}

Asian swamp eels (Monopterus sp.) were purchased in Kuala Terengganu, Malaysia. The eels were beheaded, eviscerated, filleted and de-skinned to obtain the flesh. The flesh was frozen at $-40^{\circ} \mathrm{C}$ at least within 1 week until further use. The flesh was frozen at $-40^{\circ} \mathrm{C}$ at least within 1 week until further use. The frozen flesh was thawed in a chiller overnight before thoroughly rinsed with excessive water to remove impurities. Liquid Alcalase $^{\circledR} 2.4 \mathrm{~L}(2.4 \mathrm{AU} / \mathrm{g})$ was purchased from Novo Industry (Denmark). A BLUeye pre-stained protein ladder (10-245 kDa) was purchased from GeneDirex (United Kingdom). All chemicals used were of analytical grade.

\subsection{Preparation of eel protein hydrolysate (EPH)}

Hydrolysis was performed according to the procedure of Halim and Sarbon (2016) with slight modification. For each batch, about $275 \mathrm{~g}$ of eel flesh was added to $253 \mathrm{~g}$ of distilled water. The mixture was then heated at $85^{\circ} \mathrm{C}$ for 20 mins before hydrolysis for inactivation of the endogenous enzyme. After cooling, $20 \mathrm{~g}$ of Alcalase ${ }^{\circledR}$ enzyme solution (prepared by diluting the required enzyme mass to a final weight of 20 grams with distilled water) was mixed into the eel flesh and hydrolysis was initiated immediately. Parameters of hydrolysis were temperature of $50.18^{\circ} \mathrm{C}$, time of 84.02 mins, Alcalase ${ }^{\circledR}$ to protein ratio of $2.26 \%$ and $\mathrm{pH}$ of 7.89. The hydrolysis process was carried out using water bath shaker with manual $\mathrm{pH}$ adjustment using $1 \mathrm{~N} \mathrm{NaOH}$. The hydrolysis process was terminated by heating the sample at $85^{\circ} \mathrm{C}$ for 20 mins to inactivate the Alcalase ${ }^{\circledR}$ activity. The hydrolysate was centrifuged (GYROZEN 1580R, Korea) for 20 mins at $6000 \mathrm{rpm}$, filtered and freeze-dried. The eel protein hydrolysate was stored at $40^{\circ} \mathrm{C}$ prior to analysis.
2.3 Structural properties of eel protein hydrolysate (EPH) by Fourier Transform Infrared Spectroscopy (FTIR)

In order to identify the functional groups obtained in the EPH produced, Fourier Transform Infrared (FTIR) spectroscopy (Bruker Instruments, Billerica, MA) was used. The FTIR analysis was initiated by placing EPH powder on the sample compartment of the spectroscope. The FTIR spectra of samples were obtained using a Golden-gate Diamond single reflectance ATR in a FTS 7000 FTIR spectrophotometer with a DTGS detector (Nicolet 380, USA). The spectra of EPH were recorded at the absorbance mode from 450 to $4000 \mathrm{~cm}^{-1}$ with 128 added scans at a resolution of $4 \mathrm{~cm}^{-1}$ (Halim et al., 2014).

\subsection{Solubility of eel protein hydrolysate (EPH)}

The solubility of eel protein hydrolysate (EPH) was determined using the method of Jamil et al. (2016). EPH powder was dissolved in distilled water at temperature of $60^{\circ} \mathrm{C}$ to obtain a final concentration of $2 \%(\mathrm{w} / \mathrm{v})$. The mixture was then stirred at room temperature until the hydrolysate was completely solubilized. Then, the hydrolysate was adjusted to $\mathrm{pH} 4,7$, and 10 with $1 \mathrm{~N} \mathrm{HCl}$ and $6 \mathrm{~N} \mathrm{NaOH}$. The volume of the solution was made up to $10 \mathrm{ml}$ with distilled water previously adjusted to the same $\mathrm{pH}$ of hydrolysate solution. The solution was then centrifuged (GYROZEN 1580R, Korea) at $8500 \mathrm{rpm}$ at room temperature for 10 mins. The protein content in the supernatant was determined using the Biuret method. The solubility of EPH was calculated according to the equation below:

$$
\text { Solubility }(\%)=\frac{\text { Protein content in supernatant }}{\text { Total protein content in sample }} \times 100
$$

\subsection{Emulsifying properties of eel protein hydrolysate $(E P H)$}

The emulsifying properties were determined according to the method as described by Jamil et al. (2016) with some modification. Approximately $10 \mathrm{~mL}$ of vegetable oil (Vecorn) was mixed with $30 \mathrm{~mL}$ of $1 \%$ eel protein hydrolysate $(\mathrm{EPH})$ solution and the $\mathrm{pH}$ value was adjusted to $\mathrm{pH} 4,7$ and 10 . Then, the mixture was homogenized (IKA T18 Ultra-Turrax, Malaysia) at the speed of $16,000 \mathrm{rpm}$ for $1 \mathrm{~min}$. About $50 \mu \mathrm{L}$ aliquot of an emulsion was pipetted from the bottom of the container at 0 and 10 mins after homogenization and mixed with $5 \mathrm{~mL}$ of $0.1 \%$ sodium dodecyl sulphate (SDS) solution. Using a spectrophotometer, the absorbance of the diluted solution was measured at 500 $\mathrm{nm}\left(\mathrm{A}_{500}\right)$. The absorbance was measured immediately at 0 min $\left(\mathrm{A}_{0}\right)$ and 10 mins $\left(\mathrm{A}_{10}\right)$ after the emulsion formation. The formulas used to calculate the emulsifying activity index (EAI) and the emulsion 
stability index (ESI) were as follows:

Emulsifying activity index $($ EAI $)\left(\mathrm{m}^{2} / \mathrm{g}\right)=(2 \times 2.303 \times$ $\left.\mathrm{A}_{500}\right) / 0.25 \mathrm{x}$ protein weight $(\mathrm{g})$

Emulsion stability index $(\mathrm{ESI})(\mathrm{min})=\left(\mathrm{A}_{0} \mathrm{x} \Delta \mathrm{t}\right) / \Delta \mathrm{A}$

Where $\mathrm{A}_{500}$ is the absorbance at $500 \mathrm{~nm}, \Delta \mathrm{A}$ is $\mathrm{A}_{0}-\mathrm{A}_{10}$ and $\Delta \mathrm{t}$ is time at 10 mins.

\subsection{Foaming properties of eel protein hydrolysate (EPH)}

The foaming properties were determined by using a method of Jamil et al. (2016) with modification. About $20 \mathrm{~mL}$ of $0.5 \%$ sample solution was adjusted to $\mathrm{pH} 4,7$, and 10 , followed by homogenization at a speed of 16,000 rpm, using a homogenizer to incorporate air for 2 mins at room temperature. The whipped sample was immediately transferred into a $25-\mathrm{mL}$ cylinder and the total volume was read after $30 \mathrm{~s}$. The foaming capacity was calculated using the following formula:

Foaming capacity $(\%)=[(\mathrm{A}-\mathrm{B}) / \mathrm{B}] \times 100$

Where $\mathrm{A}$ is the volume after whipping $(\mathrm{mL})$ and $\mathrm{B}$ is the volume before whipping $(\mathrm{mL})$.

The whipped sample was allowed to stand at $20^{\circ} \mathrm{C}$ for 3 mins and the volume of the whipped sample was then recorded. Foam stability was calculated as follows:

$$
\text { Foam stability }(\%)=[(\mathrm{A}-\mathrm{B}) / \mathrm{B}] \times 100
$$

Where $\mathrm{A}$ is the volume after standing $(\mathrm{mL})$ and $\mathrm{B}$ is the volume before whipping $(\mathrm{mL})$.

\subsection{Water holding capacity of eel protein hdyrolysate (EPH)}

Water holding properties were examined according to the centrifugation method described by Razali et al. (2015) with some modification. EPH samples with concentrations of $0.2 \%, 0.4 \%, 0.6 \%, 0.8 \%$ and $10.0 \%$ $(\mathrm{w} / \mathrm{v})$ were dispersed in $50 \mathrm{~mL}$ distilled water and mixed for 2 mins. The mixture was kept at room temperature for $30 \mathrm{mins}$ and then centrifuged at $5000 \mathrm{rpm}$ for 30 mins. The supernatant was filtered through a filter paper and the volume recovered was accurately measured. Water holding capacity was calculated as follows:

Water holding capacity $(\mathrm{mL} / \mathrm{g})=\frac{\text { Volume of water added }(\mathrm{mL})-\text { Volume of supernatant }(\mathrm{mL})}{\text { Mass of hydrolysate }(\mathrm{g})}$

\subsection{Oil binding capacity of eel protein hydrolysate (EPH)}

The oil binding capacity of EPH was determined according to a method by Razali et al. (2015) with slight modification. Samples with concentrations of $0.2 \%$, $0.4 \%, 0.6 \%, 0.8 \%$ and $10.0 \%(\mathrm{w} / \mathrm{v})$ were put into $50 \mathrm{~mL}$ centrifugal tubes and $10 \mathrm{~mL}$ of corn oil was added. The sample was thoroughly mixed and kept for 30 mins at $25^{\circ} \mathrm{C}$ with intermittent mixing every $10 \mathrm{mins}$, and then centrifuged (GYROZEN 1580R, Korea) at $2560 \mathrm{rpm}$ for 25 mins. Free-oil was then decanted and the oil absorption of the sample determined from the weight difference. Oil binding capacity was calculated as follows:

Oil binding capacity $(\mathrm{mL} / \mathrm{g})=\frac{\text { Volume of oil added }(\mathrm{mL})-\text { Volume of oil decanted }(\mathrm{mL})}{\text { Mass of hydrolysate }(\mathrm{g})}$

\subsection{Data analysis}

All analyses of eel protein hydrolysate (EPH) were conducted in triplicate. The data were presented as mean \pm SD. One-way ANOVA was carried out with a level of significance of $(p<0.05)$.

\section{Results and discussion}

\subsection{Preparation of eel protein hydrolysate (EPH)}

The yield of eel protein hydrolysate $(\mathrm{EPH})$ prepared was reported by Halim and Sarbon (2016) as accounting for about $6.97 \%$ of the total weight of the eel used. During the enzymatic hydrolysis process, the presence of Alcalase ${ }^{\circledR}$ catalyzed the breakdown of the eel's complex amino acid chains into several numbers of smaller and shorter amino acid chains, in which the number of peptide bonds varies depending on the enzyme concentration, hydrolysis time, $\mathrm{pH}$ value of the mixture and temperature used for hydrolysis (Srichanun et al., 2014; Jamil et al., 2016). The yield of hydrolysate produced is dependent on the number of broken peptide bonds, which is measured by the number of peptide bonds in protein mass (degree of hydrolysis $\mathrm{DH}$ ), during the entire hydrolysis process (Hamid et al., 2015; Halim and Sarbon, 2016). This means that higher DH results in a higher amount of protein hydrolysate yield. The yield of EPH produced was quite similar to the yield of freshwater carp (Catla catla) hydrolysate (6.60\%) (Elavarasan et al., 2014). However, the recorded yield was lower than the eel (Monopterus albus) protein hydrolysate produced by Jamil et al. (2016) at 9.45\%. This finding was also lower than golden apple snail (Pomacea canaliculata) hydrolysate $(9.72 \%)$ as reported by Hamid et al. (2015).

\subsection{Structural properties of eel protein hydrolysate (EPH) by Fourier Transform Infrared Spectroscopy (FTIR)}

The FTIR spectrum of eel flesh and eel protein hydrolysate $(\mathrm{EPH})$ was shown in Table 1 . Based on Table 1, it can be seen that there were shifts on $\mathrm{C}-\mathrm{H}$ stretching bands indicating the amide group from $2926.49 \mathrm{~cm}^{-1}$ found in eel flesh to a range of $2933.76 \mathrm{~cm}^{-}$ ${ }^{1}-2960.62 \mathrm{~cm}^{-1}$ in EPH. Besides that, the eel flesh and $\mathrm{EPH}$ contained proteins with secondary and tertiary 
Table 1. Fourier transform infrared (FTIR) spectrum of eel flesh and eel protein hydrolysate (EPH)

\begin{tabular}{lccc}
\hline \multicolumn{1}{c}{ Assignment } & \multirow{2}{*}{ Structural group } & \multicolumn{2}{c}{ Wavenumbers (cm $\left.^{-1}\right)$} \\
\cline { 3 - 4 } & & Eel flesh & Eel protein hydrolysate $($ EPH) \\
\hline $\mathrm{C}-$ H stretching (2970-2850) & Amide & 2926.49 & $2960.62-2933.76$ \\
$\mathrm{C}=\mathrm{O}(1760-1690)$ & $2^{\text {o }}$ and 3 ${ }^{\mathbf{0}}$ amide & $1696.57-1637.05$ & $1684.67-1647.76$ \\
$\mathrm{C}=\mathrm{C}(1600-1500)$ & Aromatic & $1577.38-1508.15$ & $1577.15-1508.26$ \\
$\mathrm{C}-$ H out-of-plane bend (910-660) & Aromatic & 668.91 & $681.39-656.72$ \\
\hline
\end{tabular}

$2^{\circ}$ (secondary); $3^{\circ}$ (tertiary)

amides at $1696.57 \mathrm{~cm}^{-1}-1637.05 \mathrm{~cm}^{-1}$ and $1684.67 \mathrm{~cm}^{-1}$ $-1647.76 \mathrm{~cm}^{-1}$, respectively. The $\mathrm{C}=\mathrm{C}$ found in both eel flesh and EPH at $1577 \mathrm{~cm}^{-1}$ to $1508 \mathrm{~cm}^{-1}$ was functional groups with aromatic rings, while the aromatic compound of the carbonyl group $(\mathrm{C}-\mathrm{H})$ in eel flesh was absorbed by infrared spectra at $669.91 \mathrm{~cm}^{-1}$, whereas in EPH, the group was found at wavenumbers $720.08 \mathrm{~cm}$ ${ }^{-1}$ and $681.39 \mathrm{~cm}^{-1}-656.72 \mathrm{~cm}^{-1}$, which correspond to the aromatic amino acids (Milewski, 2001; Skoog et al., 2007).

During the hydrolysis process, the complex eel proteins were broken down into shorter peptide chains, exposing the amide, carbonyl, carboxyl and aromatic groups in hydrolysate produced. In addition, the exposure of polar amino acids was also increased (Chalamaiah et al., 2015). According to Stuart (2004), the strongest band in the spectra is the $\mathrm{C}-\mathrm{H}$ stretching mode at $2920 \mathrm{~cm}^{-1}$, while the wavenumber of the band is 'conformative-sensitive' and responds to the changes of the trans /gauche ratio in the acyl chains. Besides that, Gunzler and Gremlich (2002) mentioned that the absorption band at the region between $1800 \mathrm{~cm}^{-1}$ and $1650 \mathrm{~cm}^{-1}$ is made up of carbonyl compounds, namely ketones, aldehydes, carboxylic acids, acid chlorides, esters, anhydrides, amide I, amide II, amide III and carboxylic acid derivatives.

The presence of polar bonds in polar functional groups of amines $\left(-\mathrm{NH}_{2}\right)$ and alcohol $(-\mathrm{OH})$ helps the polar molecules dissolve in polar solvents such as water and alcohols which increase the solubility of proteins (Taniguchi, 2010). As mentioned, polar amino acids such as Asn and Gln are found as secondary and tertiary amides at $\left(1684.67 \mathrm{~cm}^{-1}-1647.76 \mathrm{~cm}^{-1}\right)$ in EPH which will affect the solubility of EPH produced (Halim and Sarbon, 2016). Examples of polar (hydrophilic) amino acids include Asp, Glu, Lys, His, Arg, Asn, Gln, Ser and Thr. In contrast, the presence of apolar (hydrophobic) amino acids such as Gly, Ala, Val, Leu, Ile, Met, Pro, Phe, Trp and Tyr would decrease the solubility of proteins in polar solvents.

The secondary and tertiary amides found in both eel flesh and EPH might indicate the presence of asparagine (Asn) and glutamine (Gln), as reported by Halim and Sarbon (2016) in the amino acid composition of EPH. The finding was also in agreement with the previous study on amino acid composition of eel flesh and eel protein hydrolysate in which the aromatic amino acids contained in eel flesh and EPH were tyrosine $(2.15 \%$, $2.61 \%)$, phenylalanine $(2.49 \%, 3.47 \%)$ and tryptophan $(0.21 \%, 0.74 \%)$, respectively (Halim and Sarbon, 2016).

\subsection{Solubility of eel protein hydrolysate (EPH)}

The solubility of eel protein hydrolysate at different $\mathrm{pH}$ was presented in Figure 1. The highest solubility was recorded at $\mathrm{pH} 10(81.17 \%)$, followed by $\mathrm{EPH}$ at $\mathrm{pH} 4$, actual EPH and $\mathrm{EPH}$ at $\mathrm{pH} 7(79.15 \%, 76.10 \%$ and $75.06 \%$, respectively). However, there were no significant differences $(\mathrm{p}>0.05)$ on the solubility of $\mathrm{EPH}$ from $\mathrm{pH} 4$ to $\mathrm{pH} 10$. The actual $\mathrm{pH}$ value of EPH was $\mathrm{pH}$ of 8.3. The results showed EPH was soluble in broad $\mathrm{pH}$ range which was desired for protein hydrolysates as it contributes to the emulsifying and foaming properties in a food system (Pacheco-Aguilar et al., 2008). pH values influence the solubility properties of fish protein hydrolysate via the ability of peptide bond being cleavage in broad $\mathrm{pH}$ range. Thus, a variety of $\mathrm{PH}$ range will result in different properties of protein hydrolysate which causes by different level of $\mathrm{PH}$, especially in terms of its solubility.

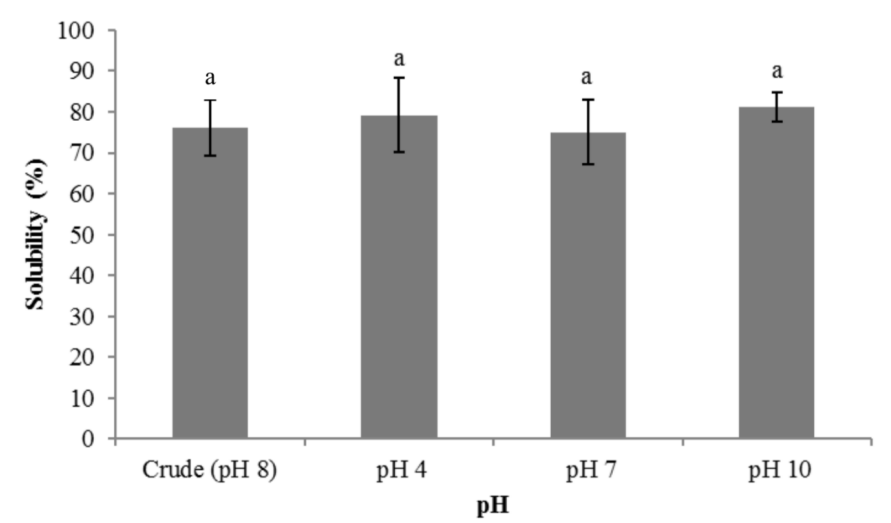

Figure 1. Solubility of eel protein hydrolysate (EPH) at $\mathrm{pH} 4$, $\mathrm{pH} 7$ and $\mathrm{pH} 10$ as compared to crude (pH 8)

Same alphabet superscript indicated no significant differences $(p>0.05)$

The high solubility of hydrolysate at PH 10 can be explained by the protein cleavage into smaller peptide units during hydrolysis (Yin et al., 2010). High solubility is also related to high degree of hydrolysis (DH) of the protein hydrolysate, in which more peptide bonds are broken down and expose the hydrophilic site of protein (Jamil et al., 2016). Besides that, the presence of 
hydrophilic amino acids has the potential to form more hydrogen bonds with water and increase hydrolysate solubility (Milewski, 2001). Furthermore, a previous study on the amino acid composition of EPH found the presence of hydrophilic amino acids, including glycine, proline, tyrosine, serine, threonine, glutamine, lysine, arginine and histidine (Halim and Sarbon, 2016).

The solubility of EPH extracted from eel flesh at $\mathrm{pH}$ 10 was in agreement to the solubility of hydrolysate from pink perch muscle hydrolyzed at $\mathrm{pH} 8.8$ (Naqash and Nazeer, 2013). In addition, the reported result was also similar with striped catfish muscle hydrolyzed at $\mathrm{pH} 7.0$ (Tanuja et al., 2012), zebra blenny muscle hydrolyzed by fermentation at pH 8.0 (Jemil et al., 2014) and eel protein hydrolysate hydrolyzed at $\mathrm{pH} 9$ by Jamil et al. (2016). In food production, an attractive appearance and 'smooth' mouth-feel of food products are from the incorporation of hydrolysate with high solubility in which EPH has the targeted property (Tanuja et al., 2012). Therefore, EPH has potential as an ingredient in human and animal food production.

\subsection{Emulsifying properties of eel protein hydrolysate (EPH)}

The emulsifying activity index (EAI) and emulsifying stability index (ESI) showed no significant differences $(\mathrm{p}>0.05)$ of EPH at all $\mathrm{pH}$ levels except for $\mathrm{pH} 4$ with the highest EAI was at $\mathrm{pH} 10\left(89.65 \mathrm{~m}^{2 /} \mathrm{g}\right)$ followed by EAI of actual EPH $\left(88.54 \mathrm{~m}^{2 / \mathrm{g}}\right)$, EAI at $\mathrm{pH}$ $7\left(72.39 \mathrm{~m}^{2 /} \mathrm{g}\right)$ and $\mathrm{pH} 4\left(4.28 \mathrm{~m}^{2 /} \mathrm{g}\right)$, while the highest ESI was at $\mathrm{pH} 4(61.57 \mathrm{~min})$ followed by ESI at $\mathrm{pH} 10$ (13.93 min), pH 7 (11.84 min) and ESI of actual EPH (11.30 $\mathrm{min})$ as presented in Table 2.

The emulsifying properties of hydrolyzed compounds are directly related to the effectiveness of hydrolysate compound in reducing the interfacial tension between the hydrophobic and hydrolytic components in food products (Cho et al., 2008). Environmental $\mathrm{pH}$ could significantly affect the emulsifying properties of hydrolysate by changing the surface hydrophobicity and charge of the protective layer surrounding the lipid globules (Taheri et al., 2013).

Besides the $\mathrm{pH}$ level, the amino acids composition of the eel protein hydrolysate (EPH) also contributes to its emulsifying properties. The presence of hydrophobic amino acids could influence the emulsifying properties of hydrolysates produced (Cho et al., 2008). A previous study on amino acid composition of EPH found the presence of hydrophobic amino acids such as leucine $(6.52 \%)$, isoleucine $(4.35 \%)$, alanine $(5.01 \%)$ and hydrophilic amino acids such as histidine $(2.25 \%)$, serine (3.46\%) and glutamine (13.28\%) (Halim and Sarbon, 2016). The amino acid determination for EPH showed that this hydrolysate contains hydrophobic and hydrophilic amino acids involved in the oil-in-water interaction of EPH. Studies have shown that the EAI of fish protein hydrolysates was the highest at $\mathrm{pH} 6-\mathrm{pH}$ 10, while the lowest at $\mathrm{pH} 4$ (Pacheco-Aguilar et al., 2008; Naqash and Nazeer, 2013) which was in agreement with the results obtained in this study.

\subsection{Foaming properties of eel protein hydrolysate (EPH)}

Table 2 shows that the $\mathrm{pH}$ significantly $(\mathrm{p}<0.05)$ affect the foaming capacity and stability of eel protein hydrolysate (EPH) in which EPH at $\mathrm{pH} 7$ had the highest foaming capacity and stability $(92.50 \%$ and $61.67 \%)$, respectively. The foaming properties were the least at $\mathrm{pH}$ 4 and it can be seen that the foaming properties decreased as the $\mathrm{pH}$ increases from $\mathrm{pH} 7$ to $\mathrm{pH} 10$. The molecules of EPH at pH 7 may have a well-ordered orientation, in which the hydrophilic head is located in the aqueous phase and hydrophobic tail faces non-polar components, resulting in the most stable foam among all $\mathrm{pH}$ levels.

Generally, foaming properties of protein hydrolysates were related to the transportation, penetration and rearrangement of molecules at the hairwater interface (Elavarasan et al., 2014). Thus, good foaming properties depend on the ability of hydrolysates to rapidly absorb into the air-water interface and rearrange their structures, as well as having several molecular characteristics such as good surface balance, charge distribution, and molecular hydrophobicity (Pacheco-Aguilar et al., 2008).

A foam was formed when protein dispersed in low water tension at the air-water interface (Tanuja et al., 2012). Besides that, foaming properties were also affected by low molecular weight (MW) of the

Table 2. Emulsifying properties and foaming properties of eel protein hydrolysate (EPH) at different $\mathrm{pH}$

\begin{tabular}{lcccc}
\hline \multirow{2}{*}{ Functional Properties } & \multicolumn{4}{c}{$\mathrm{pH}$} \\
\cline { 2 - 5 } & Crude $(\mathrm{pH} \mathrm{8)}$ & $\mathrm{pH}$ & $\mathrm{pH}$ & $\mathrm{pH} 10$ \\
\hline Emulsifying Activity Index (EAI) $\left(\mathrm{m}^{2} / \mathrm{g}\right)$ & $88.54 \pm 13.82^{\mathrm{a}}$ & $4.28 \pm 0.15^{\mathrm{b}}$ & $72.39 \pm 6.07^{\mathrm{a}}$ & $89.65 \pm 4.19^{\mathrm{a}}$ \\
Emulsifying Stability Index (ESI) (min) & $11.30 \pm 0.51^{\mathrm{b}}$ & $61.57 \pm 14.17^{\mathrm{a}}$ & $11.84 \pm 0.31^{\mathrm{b}}$ & $13.93 \pm 1.28^{\mathrm{b}}$ \\
Foaming Capacity (\%) & $92.50 \pm 2.17^{\mathrm{a}}$ & $85.83 \pm 3.82^{\mathrm{b}}$ & $92.50 \pm 2.50^{\mathrm{a}}$ & $91.08 \pm 0.14^{\mathrm{ab}}$ \\
Foaming Stability (\%) & $54.17 \pm 6.29^{\mathrm{ab}}$ & $42.08 \pm 0.72^{\mathrm{b}}$ & $61.67 \pm 4.02^{\mathrm{a}}$ & $47.83 \pm 2.02^{\mathrm{b}}$ \\
\hline
\end{tabular}

Different alphabet superscripts indicated significant differences $(p<0.05)$ 
Table 3. Water holding capacity and oil binding capacity of eel protein hydrolysate (EPH) at different concentration

\begin{tabular}{lccccc}
\hline \multirow{2}{*}{ Functional Properties } & \multicolumn{5}{c}{ Concentration } \\
\cline { 2 - 6 } & $0.20 \%$ & $0.40 \%$ & $0.60 \%$ & $0.80 \%$ & $1.00 \%$ \\
\hline Water Holding Capacity (WHC) $(\mathrm{mL} / \mathrm{g})$ & $37.53 \pm 5.96^{\mathrm{a}}$ & $20.82 \pm 13.72^{\mathrm{ab}}$ & $7.90 \pm 1.54^{\mathrm{b}}$ & $6.65 \pm 1.89^{\mathrm{b}}$ & $6.46 \pm 2.09^{\mathrm{b}}$ \\
Oil Binding Capacity (OBC)(mL/g) & $0.44 \pm 0.24^{\mathrm{a}}$ & $0.35 \pm 0.04^{\mathrm{a}}$ & $0.50 \pm 0.08^{\mathrm{a}}$ & $0.45 \pm 0.02^{\mathrm{a}}$ & $0.56 \pm 0.13^{\mathrm{a}}$ \\
\hline
\end{tabular}

Different alphabet superscripts indicated significant differences $(\mathrm{p}<0.05)$

hydrolysate, as low MW hydrolysate was unable to maintain well-ordered, interface orientation of the molecule (Nalinanon et al., 2011). Based on Table 2, the foaming stability of EPH at all $\mathrm{pH}$ levels was lower than the foaming capacity. The findings in this study are similar to those of a study by Naqash and Nazeer (2013) on pink perch muscle hydrolysate in which the foaming properties decreased at $\mathrm{pH} 4$ and increased as the $\mathrm{pH}$ increases. In contrast, the results were higher than the foaming capacity of Spanish mackerel hydrolysate (65.0\%) as reported by Chi et al. (2014).

\subsection{Water holding capacity of eel protein hydrolysate (EPH)}

The water holding capacity of eel protein hydrolysate $(\mathrm{EPH})$ was significantly decreased $(\mathrm{p}<0.05)$ with increasing hydrolysate concentration from $0.2 \%$ to $1.0 \%$ (Table 3). The result showed that at $0.1 \% \mathrm{EPH}$ had the highest surface area to mass ratio, resulting in the highest water holding capacity. In contrast, EPH with a concentration of $1.0 \%$ had the least exposed surface that can be imbibed with water, thus decreasing its holding capacity. During the hydrolysis process, the complex protein is broken down into shorter amino acids chains, exposing the $\mathrm{N}$-terminal (polar groups) which is ready to bind with $\mathrm{H}$-bond of water.

Water holding capacity is referred to as the ability of protein to imbibe water and retain in against a gravitational force within a protein matrix (Foh et al., 2010). A higher water holding capacity shows higher surface area to the mass ratio in hydrolysate which is ready to interact with $\mathrm{H}$-bond of water (Slizyte et al., 2009). The low molecular weight hydrolysate and the increased concentrations of polar groups exposed during the breakdown of amino acid chains were able to increase the water holding capacity of hydrolysate (Taheri et al., 2013). The presence of hydrophilic polar group amino acids in EPH such as serine, threonine, asparagine, and glutamine might also influence the water holding capacity of the hydrolysate, which is important in the increasing of cooking yield (Halim and Sarbon, 2016). The water holding capacity of EPH was higher than those of hydrolysates produced from bluewing searobin $(3.75 \mathrm{~mL} / \mathrm{g})$, tilapia $(1.77-2.10 \mathrm{~mL} / \mathrm{g})$ and zebra blenny $(6.10 \mathrm{~mL} / \mathrm{g})$ muscles (dos Santos et al., 2011; Foh et al., 2011; Jemil et al., 2014).

\subsection{Oil binding capacity of eel protein hydrolysate (EPH)}

Table 3 shows the oil binding capacity of eel protein hydrolysate $(\mathrm{EPH})$ at different concentrations $(0.2 \%$, $0.4 \%, 0.6 \%, 0.8 \%$ and $1.0 \%$ ). The EPH at $1.0 \%$ showed the highest oil binding capacity, followed by EPH at $0.6 \%, 0.8 \%, 0.2 \%$, and $0.4 \%$. However, the oil binding capacity of EPH showed no significant differences $(p>0.05)$ at different hydrolysate concentrations.

The oil binding capacity of EPH was lower than the water binding capacity. This may be due to the higher amount of polar than non-polar groups at the N-terminal of amino acids chains. Hence, EPH demonstrated lower oil binding as compared to water binding. According to dos Santos et al. (2011), oil binding capacity is correlated to the surface's hydrophobicity of protein. Based on these findings, it may be said that EPH at different concentrations showed similar surface hydrophobic properties, making it able to bind with oil. In addition, the bulk density of peptides and enzyme/ substrate specificity also influence the oil binding capacity of protein hydrolysates (Cho et al., 2008).

The ability of hydrolysate to absorb oil is important to influence the taste of products such as meat, salad dressings, bakery products and confectionaries, as well as their functional characteristics (Cho et al., 2008; dos Santos et al., 2011). Therefore, EPH was found to have the ability to binding oil in food products. However, EPH at all concentrations had oil binding capacity of less than $1.00 \mathrm{ml} / \mathrm{g}$, lower than the oil binding capacity of that from striped catfish $(1.35 \mathrm{~mL} / \mathrm{g})$, and dagaa $(3.50$ $\mathrm{mL} / \mathrm{g}$ ) muscle hydrolysates (Tanuja et al., 2012; Betty et al., 2014).

\section{Conclusion}

In conclusion, the hydrolysis process of eel protein using Alcalase ${ }^{\circledR}$ promotes the breakdown of large numbers of shorter amino acid chains exposed to hydrophilic and hydrophobic groups of protein, resulting in changes of structural groups and lower molecular weight proteins with functional properties comparable to other fish protein hydrolysates produced. The eel protein hydrolysate (EPH) had significant functional groups of primary and secondary amides, which indicate the presence of hydrophilic and hydrophobic amino acids. The structural analysis of EPH also found the presence 
of aromatic groups related to the existence of amino acids with an aromatic ring in EPH. The EPH also showed significant differences $(p<0.05)$ in emulsifying properties and foaming properties at different $\mathrm{pH}$ and water holding capacity at different concentration of EPH. The results obtained showed that the EPH has potential as a good source of food emulsifiers and stabilizers in processed food products.

\section{Acknowledgements}

With sincere appreciation, the authors gratefully acknowledge the Ministry of Higher Education for its financial support through the Research Acculturation Collaborative Effort (RACE) grant scheme (RACE/F2/ $\mathrm{SS} / \mathrm{UMT} / 12 / 56025)$; and the Universiti Malaysia Terengganu for its laboratory facilities and technical support.

\section{References}

Baharuddin, N.A., Halim, N.R.A. and Sarbon, N.M. (2016). Effect of degree of hydrolysis (DH) on the functional properties and angiotensin I-converting enzyme (ACE) inhibitory activity of eel (Monopterus sp.) protein hydrolysate. International Food Research Journal, 23, 1424-1431.

Betty, M., Awuor, O.L., Kirwa, M.E. and Jackim, M.F. (2014). Antioxidative and functional properties of Rastrineobola argentea (Dagaa) fish protein hydrolysate. Disc. Journal of Agriculture Food Science, 2(6), 180-189.

Chalamaiah, M., Jyothirmayi, T., Diwan, P.V. and Kumar, B.D. (2015). Antioxidant activity and functional properties of enzymatic protein hydrolysates from common carp (Cyprinus carpio) roe (egg). Journal of Food Science Technology, 52 (9), 5817-5825. https://doi.org/10.1007/s13197-015$1714-6$

Chalamaiah, M., Kumar, B.D., Hemalatha, R. and Jyothirmayi, T. (2012). Fish protein hydrolysates: Proximate composition, amino acid composition, antioxidant activities and applications: A review. Food Chemistry, 135(4), 3020-3038. https:// doi.org/10.1016/j.foodchem.2012.06.100

Chi, C., Cao, Z., Wang, B., Hu, F., Li, Z. and Zhang, B. (2014). Antioxidant and functional properties of collagen hydrolysates from Spanish mackerel skin as influenced by average molecular weight. Molecules, 19(8), 11211-11230. https://doi.org/10.3390/ molecules190811211

Cho, S.S., Lee, H.K., Han, C.W., Seong, E.S., Yu, C.Y., Kim, M.J., Kim, N.Y., Kang, W.S., Ko, S.H., Son, E.H., Choung, M.G. and Lim, J.D. (2008).
Physicochemical properties of isolated peptides from hwangtae (yellowish dried Pollack) protein hydrolysate. Journal of Food Science Nutritional, 13, 204-211. https://doi.org/10.3746/ jfn.2008.13.3.204

dos Santos, S.A., Martins, V.G., Sallas-Mellado, M. and Prentice, C. (2011). Evaluation of functional properties in protein hydrolysates from bluewing searobin (Prionotus punctatus) obtained with different microbial enzymes. Food and Bioprocess Technology, 4(8), 1399-1406. https:// doi.org/10.1007/s11947-009-0301-0

Elavarasan, K., Naveen Kumar, V. and Shamasundar, B.A. (2014). Antioxidant and functional properties of $(\mathrm{FPH})$ from freshwater carp (Catla catla) as influenced by the nature of enzyme. Journal of Food Process and Preservation, 38(3), 1207-1214. https:// doi.org/10.1111/jfpp.12081

Foh, M.B.K., Amadou, I., Foh, B.M., Kamara, M.T. and Xia, W.S. (2010). Functionality and antioxidant properties of tilapia (Oreochromis niloticus) as influenced by the degree of hydrolysis. International Journal of Molecular Science, 11(4), 1851-1869. https://doi.org/10.3390/ijms11041851

Foh, M.B.K., Kamara, M.T., Amadou, I., Foh, B.M. and Wenshui, X. (2011). Chemical and physicochemical properties of tilapia (Oreochromis niloticus) fish protein hydrolysate and concentrate. International Journal of Biological Chemical, 5(1), 1-15. https:// doi.org/10.3923/ijbc.2011.21.36

Gunzler, H. and Gremlich, H. (2002). IR Spectroscopy: An Introduction. Weinheim: Wiley-VCH.

Halim, N.R.A. and Sarbon, N.M. (2016). A response surface approach on hydrolysis condition of eel (Monopterus sp.) protein hydrolysate with antioxidant activity. International Food Research Journal, 24(3), 1081-1093.

Halim, N.R.A., Shukri, W.H.W.Z., Lani, M.N. and Sarbon, N.M. (2014). Effect of different types of hydrocolloids on physical and sensory properties of ice cream with fermented glutinous rice (tapai pulut). International Food Research Journal, 21(5), 1777-1787.

Halim, N.R.A., Yusof, H.M. and Sarbon, N.M. (2016). Functional and bioactive properties of fish protein hydrolysates and peptides: A comprehensive review. Trends in Food Science Technology, 51, 24-33. https://doi.org/10.1016/j.tifs.2016.02.007

Hamid, S.A., Halim, N.R.A. and Sarbon, N.M. (2015). Optimization of enzymatic hydrolysis conditions of Golden Apple snail (Pomacea canaliculata) protein by Alcalase. International Food Research Journal, 
22(4), 1615-1623.

Hill, J.E. and Watson, C.A. (2007). Diet of the nonindigenous Asian Swamp Eel in Tropical Ornamental Aquaculture Ponds in West-Central Florida. North American Journal of Aquaculture, 69 (2), 139-146. https://doi.org/10.1577/A05-070.1

Intarasirisawat, R., Benjakul, S., Visessanguan, W. and $\mathrm{Wu}$, J. (2012). Antioxidative and functional properties of protein hydrolysate from defatted skipjack (Katsuwonous pelamis) roe. LWT- Food Chemistry, 135(4), 3039-3048. https:// doi.org/10.1016/j.foodchem.2012.06.076

Ishak, N.H. and Sarbon, N.M. (2016). Optimization of enzymatic hydrolysis condition of shortfin scad (Decapterus macrosoma) waste for production of ACE inhibitory peptide by RSM. International Food Research Journal, 24(4), 1735-1743.

Jamil, N.H., Halim, N.R.A. and Sarbon, N.M. (2016). Optimization of enzymatic hydrolysis condition and functional properties of eel (Monopterus $s p$.) protein using response surface methodology (RSM). International Food Research Journal, 23(1), 1-9.

Jemil, I., Jridi, M., Nasri, R., Ktari, N., Salem, R.B.S., Mehiri, M., Hajji, M. and Nasri, M. (2014). Functional, antioxidant and antibacterial properties of protein hydrolysates prepared from fish meat fermented by Bacillus subtilis A26. Process Biochemistry, 49(6), 963-972. https:// doi.org/10.1016/j.procbio.2014.03.004

Khanh, N.H. and Ngan, H.T.B. (2010). Current practices of rice field eel (Monopterus albus) culture in Vietnam. Research International Aquaculture, 3, 2629.

Li, Z., Wang, B., Chi, C., Gong, Y., Luo, H. and Ding, G. (2013). Influence of average molecular weight on antioxidant and functional properties of cartilage collagen hydrolysates from Sphyrna lewini, Dasyatis akjei and Raja porosa. Food Research International, 51(1), 183-193. https://doi.org/10.1016/ j.foodres.2012.12.031

Milewski, S. (2001). Protein structure and physicochemical properties. In Sikorski Z.E (Ed). Chemical and functional properties of food proteins, p. 40. Pennsylvania: Technomic Publishing Company Inc.,

Molla A.E. and Hovannisyan, H.G. (2011). Optimization of enzymatic hydrolysis of visceral waste proteins of beluga Huso using Protamex. International Aquatic Research, 3, 93-99.

Nalinanon, S., Benjakul, S., Kishimura, H. and Shahidi, F. (2011). Functionalities and antioxidant properties of protein hydrolysates from the muscle of ornate threadfin bream treated with pepsin from skipjack tuna. Food Chemistry, 124(4), 1354-1362. https:// doi.org/10.1016/j.foodchem.2010.07.089

Naqash, S.Y. and Nazeer, R.A. (2013). Antioxidant and functional properties of protein hydrolysates from pink perch (Nemipterus japonicas) muscle. Journal of Food Science Technology, 50(5), 972-978. https:// doi.org/10.1007/s13197-011-0416-y

Pacheco-Aguilar, R., Mazorra-Manzano, M.A. and Ramirez-Suarez, J.C. (2008). Functional properties of (FPH) from Pacific whiting (Merluccius productus) muscle produced by a commercial protease. Food Chemistry, 109(4), 782-789. https:// doi.org/10.1016/j.foodchem.2008.01.047

Pederson, P.B.M., Hansen, K., Huong, D.T.T., Bayley, M. and Wang, T. (2014). Effects of salinity on osmoregulation, growth and survival in Asian swamp eel (Monopterus albus) (Zuiew 1793). Aquaculture Research, 45(3), 427-438. https:// doi.org/10.1111/j.1365-2109.2012.03244.x

Prabha, J, Narikimelli, A., Sajini, M.I. and Vincent, S. (2013). Optimization for autolysis assisted production of fish protein hydrolysate from underutilized fish Pellona ditchela. International Journal Science Engineering Research, 4(12), 18631869.

Razali, A.N., Sarbon, N.M. and Amiza, M.A. (2015). Antioxidant activity and functional properties of fractionated cobia skin gelatin hydrolysate at different molecular weight. International Food Research Journal, 22(2), 651-660.

Roslan, J., Siti Mazlina, M.K., Yunos, K.F.M. and Abdullah, N. (2014). Optimization of enzymatic hydrolysis of tilapia muscle (Oreochromis niloticus) using response surface methodology (RSM). Sains Malaysiana, 43(11), 1715-1723.

Skoog, D.A., Holler, F.J. and Crouch, S.R. (2007). Principles of instrumental analysis. 6th ed. California: Brooks/Cole Cengage Learning.

Slizyte, R., Mozuraityte, R., Martinez-Alvarez, O., Falch, E., Fouchereau-Peron, M. and Rustad, T. (2009). Functional, bioactive, and antioxidative properties of hydrolysates obtained from cod (Gadus morhua) backbones. Process Biochemistry, 44(6), 668-677.

https://doi.org/10.1016/ j.procbio.2009.02.010

Srichanun, T., Kortner, T.M., Krogdahl, A. and Chotikachinda, R. (2014). Effects of different protein hydrolysate products and levels on growth, survival rate and digestive capacity in Asian seabass (Lates calcarifer Bloch) larvae. Aquaculture, 428-429, 195202. 
j.aquaculture.2014.03.004

Stuart, B. (2004). Infrared spectroscopy: Fundamentals and applications. New York: Wiley. https:// doi.org/10.1002/0470011149

Taheri, A., Anvar, S.A.A., Ahari, H. and Fogliano, V. (2013). Comparison the functional properties of protein hydrolysates from poultry by-products and rainbow trout (Onchorhynchus mykiss) viscera. Iranian Journal Fisheries Science, 12(1), 154-169.

Taniguchi, N. (2010). Amino acid and proteins. Medic Biochemistry, 3, 5-21. https://doi.org/10.1016/B9780-323-05371-6.00002-4

Tanuja. S., Viji, P., Zynudheen, A.A. and Joshy, C.G. (2012). Composition, functional properties and antioxidative activity of hydrolysates prepared from the frame meat of striped catfish (Pangasianodon hypophthalmus). Egyptian Journal of Biological, 14, 27-35. https://doi.org/10.4314/ejb.v14i1.3

Wang, W., Li, Z., Liu, J., Wang, Y., Liu, S. and Sun, M. (2013). Comparison between thermal hydrolysis and enzymatic proteolysis process for the preparation of tilapia skin collagen hydrolysates. Czech Journal of Food Science, 31(1), 1-4. https:// doi.org/10.17221/49/2012-CJFS

Yanan, Z., Li, Z., Hua, L., Wei, S. and Meilan, Y. (2012). Effect of eel head protein hydrolysates on the denaturation of grass carp surimi during frozen storage. Procedia Engineering, 37, 223-228. https:// doi.org/10.1016/j.proeng.2012.04.231

Yin, H., Pu, J., Wan, Y., Xiang, B., Bechtel, P.J. and Sathivel, S. (2010). Rheological and functional properties of catfish skin protein hydrolysates. Journal of Food Sceince, 75(1), 1-17. https:// doi.org/10.1111/j.1750-3841.2009.01385.x 